Int. J. Electrochem. Sci., 11 (2016) 10287 - 10295,

\title{
Analysis of Thermal Runaway Aftereffects in Nickel-Cadmium Batteries
}

\author{
Nataliya N. Yazvinskaya ${ }^{1}$, Nikolay E. Galushkin ${ }^{1, *}$, Dmitriy N. Galushkin ${ }^{1}$, Inna A. Galushkina ${ }^{2}$ \\ ${ }^{1}$ Don State Technical University, Laboratory of electrochemical and hydrogen energy, 147 \\ Shevchenko Street, Town of Shakhty, Rostov Region, Russia, 346500. \\ ${ }^{2}$ Southern Federal University, Novoshakhtinsk branch, 2 Oktiabria Street, Town of Novoshakhtinsk, \\ Rostov Region, Russia, 346900. \\ *E-mail: galushkinne@mail.ru
}

doi: $10.20964 / 2016.12 .44$

Received: 10 September 2016 / Accepted: 5 October 2016 / Published: 10 November 2016

In this research, there were obtained and analyzed experimental facts contradicting to the classical mechanism of the thermal runaway in nickel-cadmium batteries. It was shown that all the obtained experimental facts are in exact accordance to the new mechanism of thermal runaway consisting in the colligation of the thermal runaway with a powerful exothermic reaction initiation of the atomic hydrogen recombination.

Keywords: thermal runaway, battery, nickel-cadmium

\section{$\underline{\text { FULL TEXT }}$}

(C) 2016 The Authors. Published by ESG (www.electrochemsci.org). This article is an open access article distributed under the terms and conditions of the Creative Commons Attribution license (http://creativecommons.org/licenses/by/4.0/). 